\title{
Preceptors in Medical Residency Programs: Epidemiological Profile and Pedagogic Training
}

\author{
Preceptores de Residência Médica: Perfil Epidemiológico e \\ Capacitação Pedagógica
}

\author{
Aderval de Melo Carvalho Filho ${ }^{I, I}$ \\ Almira Alves dos Santos ${ }^{I}($ it) \\ Rozangela Maria de Almeida Fernandes Wyszomirska ${ }^{I, I I} \mathbb{D}$ \\ Isabella Costa Figueiredo Medeiros ${ }^{I}(\mathbb{D}$
}

\section{KEYWORDS}

- Preceptor(s).

- Medical Preceptorship.

- Medical Residency.

Introduction: Medical Residency is a specialization course characterized as in-service training, considered in Brazil as the gold standard in the development of specialist physicians' training. The medical residency preceptorship is an activity carried out by a specialist physician, responsible for monitoring resident physicians. However, there is neither a definition of the main requirements for such a preceptor, nor of his/her academic background to carry out the due teaching training, and it was possible to notice a relative lack of preparation regarding the pedagogical aspects. Methods: Descriptive study based on a quantitative approach, comprising 200 preceptors, of both genders, from medical residency programs in Maceió, state of Alagoas, Brazil. Results: The mean age was $43.31 \pm 10.31$ years, with a slight majority of female participants (52.5\%). The mean time since graduation was $19.5 \pm 10.58$ years, and $83 \%$ of the participants had graduated in the state of Alagoas. Moreover, $78.5 \%$ said they had their Medical Residency certification, with an increased trend of public institution preceptors getting their degree at the stricto sensu level. The mean time of their completed postgraduate course was $12.63 \pm 10.87$ years and $7.07 \pm 6.99$ years being a preceptor. Only $19 \%$ mentioned they had some qualification for exercising the preceptorship, and 29.5\% work as the teachers at the undergraduate level. The state of Alagoas has followed the expansion of the Residency programs, justifying the mean age found, similar to other studies. The majority of female participants can be associated with the feminization of health care professionals. The high percentage of preceptors with medical residency qualification is in accordance with Resolution n. 4/1978. We found experienced preceptors, but some authors differed. The low percentage of preceptors with qualification for exercising preceptorship indicates low interest and lack of available training. Conclusion: This study population is characterized as being young, and most are females. They have had long professional experience, and most have graduated in the state of Alagoas. There is a predominance of medical residency as their main qualification, and few of them have had training in the field. Finally, preceptors from public institutions have mostly got their degrees at the stricto sensu level. 


\section{RESUMO}

\section{PALAVRAS-CHAVE}

- Preceptor(es)

- Preceptoria.

- Residência Médica.

Introdução: A residência médica é uma modalidade de pós-graduação, caracterizada como treinamento em serviço, considerada no Brasil como padrão-ouro na formação de médicos especialistas. A preceptoria na residência médica é desenvolvida por um especialista que, além ser responsável pelo residente, prepara-o para a prática profissional. Como ainda não há definição dos principais requisitos para o preceptor, nem sobre a preparação para o exercício, percebe-se relativo despreparo quanto aos aspectos pedagógicos e de capacitação. Método: Trata-se de um estudo descritivo, de abordagem quantitativa, realizado com 200 preceptores de ambos os sexos, de programas de residência médica em Maceió, em Alagoas. Resultados: A média de idade encontrada foi de 43,31 \pm 10,31 anos, com discreta maioria do sexo feminino (52,5\%). O tempo médio de conclusão da graduação foi de 19,5 \pm 10,58 anos, com 83\% dos participantes graduados em Alagoas. Além disso, 78,5\% possuem a certificação de residência médica, havendo maior tendência dos preceptores de instituições públicas em obter titulação em pós-graduações stricto sensu. O tempo médio da pós-graduação concluída foi de 12,63 $\pm 10,87$ anos; e o de exercício da preceptoria, de 7,07 $\pm 6,99$ anos. Apenas $19 \%$ dos preceptores referiram capacitação para a preceptoria, e 29,5\% atuam como docentes na graduação. Alagoas acompanhou a tendência nacional de ampliação da PRM, o que pode justificar a idade média encontrada, semelhante a outros estudos. A maioria do sexo feminino pode estar associada a um processo de feminização da saúde. A alta porcentagem de preceptores titulando a residência médica está em sintonia com a Resolução $n^{\circ} 4 / 78$. Neste estudo foram encontrados preceptores experientes, constatação que diverge dos achados de alguns autores. A baixa porcentagem de preceptores com capacitação para a preceptoria indica baixo interesse, falta de estímulos e pouca oferta de treinamentos disponíveis. Conclusão: A população deste estudo é de preceptores predominantemente jovens, com maioria do sexo feminino, que possuem tempo elevado de experiência, e a maioria graduou-se em Alagoas. Houve predomínio da residência médica como principal titulação, e a maioria dos preceptores não recebeu capacitação pedagógica para a função. Por fim, os preceptores de instituições públicas possuem maior proporção de títulos de pós-graduação stricto sensu.

Received on $5 / 1 / 20$

Accepted on $9 / 15 / 20$

\section{INTRODUCTION}

The Brazilian Unified Health System (SUS, Sistema Único de Saúde) was established by the Brazilian Federal Constitution of 1988 and was based on a broad understanding of the right to health and the role of the Government in guaranteeing this right. In its Article n. 200, SUS competences are defined, including that of directing the training of human resources in the health field ${ }^{1}$. This is an important commitment because, according to Antunes et al. ${ }^{2}$, the training of health professionals must meet the demands of SUS with quality and efficiency, as well as the needs of its users, with a greater emphasis on primary care.

Included in this context of Public Health and the training of health professionals, Medical Residency (MR) was regulated in Brazil according to Decree n. 80.281 of September 5, 1977 ${ }^{3}$, being established as a lato sensu postgraduate teaching modality, aimed at the formation of medical doctors, as a form of specialization and characterized as in-service training. In the MR, the resident physician (usually a recently graduated one) is offered the opportunity to deepen their knowledge and experience in specific specialties, as well as attaining professional development. Moreover, MR is also considered the gold standard in the training of specialist doctors in the country and is also characterized by operating in health institutions (either in a university environment or not), under special in-service training, comprising a total of 60 (sixty) hours of work per week ${ }^{4}$. This modality is developed through guidance and intensive monitoring, carried out by doctors with high ethical and professional qualification ${ }^{3,5}$. Although medical training is considered to be completed at graduation, the MR becomes a fundamental strategy for improvement, complementing the professional training of doctors and facilitating their inclusion in the job market ${ }^{6}$.

Medical Residency Programs (MRPs) must be accredited by the National Medical Residency Commission (CNRM, Comissão Nacional de Residência Médica) and the residents, after fully completing the program within a specialty, receive the title of specialist ${ }^{7}$. Data from 2017 show that, in that year, there were 35,187 doctors attending MR, distributed in 6,574 MRPs in more than 790 institutions accredited by $\mathrm{CNRM}^{8}$.

Preceptorship for Medical Residency

According to Mills, Francis et al. ${ }^{9}$, preceptorship can be defined as a teaching-learning activity carried out by the preceptor's monitoring, aiming to prepare this student for professional practice. In this perspective, the residents will have the opportunity to develop their clinical and ethical sense, thus being able to work in the same environment where the preceptors develop their assistance activities. The preceptor is a medical practice professional who undertakes several functions during the process of training the resident, acting as a tutor, stimulating the reasoning and guiding the residents' ethical posture; in this context, they plan, control and evaluate the entire learning process ${ }^{10}$. Moreover, the preceptors must also have the ability to prepare the residents professionally, so they can learn how to act competently in multiprofessional environments, in order to fully meet the needs of the users ${ }^{11}$.

According to Botti ${ }^{12}$, the importance of the preceptors is observed by the proximity and participation they have regarding the training of the resident, which makes them the actors with the greatest potential for

REVISTA BRASILEIRA DE EDUCAÇÃO MÉDICA

2 44 (4) : e159; 2020 
monitoring this teaching-learning process. In Brazil, the term "preceptor" was initially used in Medical Residency programs, and its use was extended to the training of health professionals in all areas, both in undergraduate and postgraduate courses ${ }^{13}$.

Decree n. $80.281 / 1977^{3}$, on the regulation of the MR, mentions the preceptorship, saying the guidance of the residents should be carried out by doctors with high ethical and professional qualification. However, this decree did not define what this high qualification would be ${ }^{3}$. In 2006, a new resolution of the CNRM (02/2006) defined some criteria regarding the profile of those who could supervise the residents: teachers, doctors with a certificate that proves the completion of medical residency, or the title of specialist, or even those who have an equivalent qualification ${ }^{14}$. Nonetheless, it can be observed that the preceptor's work agenda remains poorly structured, being subject to the presence of demands that are external to the resident's training and monitoring activity, such as service management activities, or medical care; in addition to showing a lack of conceptual appropriation in relation to pedagogical competence, in which the preceptor is seen only as a technical reference, with professional competence in that specialty ${ }^{15}$.

The training for the function of preceptor and its corresponding duties, as well as the responsibilities in medical education, are subjects of discussion in most medical education institutions in Brazil; however, there is a small number of articles published on the subject. Existing studies report that the preceptors are relatively unprepared regarding the pedagogical aspects or training for preceptorship, resulting in lowquality educational activity, with probable interference in the training of resident physicians ${ }^{16,17,18}$. Botti ${ }^{12}$ observed that the educational training index reaches a maximum of $50 \%$; in another study, with MR preceptors in the field of Anesthesiology, it was observed that $96.6 \%$ reported having only MR as their highest academic degree. ${ }^{19}$ A technical performance of excellence by the preceptor does not necessarily guarantee a good teaching performance, that is, the simple fact of carrying out their assistance activities with competence does not necessarily guarantee that the preceptors have the teaching skills necessary to teach their students how to perform the practice ${ }^{20}$.

In a study with MR preceptors in Pediatrics, those who had some pedagogical training, had it due to the disciplines in the stricto sensu postgraduate courses carried out due to their own interest, without any direct initiative or encouragement by the MRP coordination or even the institution where they worked ${ }^{21}$. Castells ${ }^{15}$ reported that the preceptors were concerned about their lack of mastery of certain skills for preceptorship, being aware of the importance of training and the acquisition of pedagogical skills for the adequate exercise of their functions as preceptors, while another study also shows that preceptors demand the offer of permanent education courses, either in person or distance training, especially in the health education area ${ }^{22}$. Some existing initiatives can be observed, which encourage the training of preceptors, such as that by the Regional Council of Medicine of Paraná ${ }^{23}$ or by medical specialty societies ${ }^{24}$, providing manuals with the objective of valuing this fundamental learning aspect of MR. There are also national programs, such as the training of preceptors for the Family and Community Medicine specialty ${ }^{25}$.

Based on what was exposed here, and due to the few studies about preceptors in MR in the northeastern region, the need and the interest to analyze the pedagogical characteristics and the epidemiological profile of the preceptors of Medical Residences in the municipality of Maceió, capital of the state of Alagoas, emerged.

\section{METHODS}

This research was developed in the Postgraduate Program in Health Teaching and Technology - Professional Master's Degree - at the Universidade Estadual de Ciências da Saúde de Alagoas (UNCISAL). This is a descriptive study with a quantitative approach. Data collection was carried out between the months of September 2019 and January 2020. The study population consisted of 200 preceptors, considering the preceptor as the specialist physician who worked with the resident physicians in the construction of specific knowledge in their area regarding the different MRP practice scenarios.

The inclusion criterion comprised the preceptors who were working during the data collection period and the exclusion criteria comprised the preceptors who, for some reason, were away from their respective MRPs during this period.

Using a previous invitation sent to the preceptors, inviting them to participate in this research, an appointment was made to complete the questionnaires, at which time the interviewees received clarifications about the stages of the research, its objectives and its relevance, while also ensuring data confidentiality. Finally, the Free and Informed Consent (FIC) form was handed to the participants, to be read and signed. Aiming to preserve their anonymity, all preceptors were identified by the letter $\mathrm{P}$ and their respective number.

After completing and signing the FIC form, the research participants answered a questionnaire containing simple questions, aiming to obtain their general (gender, age) and sociodemographic data (year of graduation, academic title, time of experience as a preceptor, weekly hours working as a preceptor, type of employment link with the educational institutions and area of activity, among others).

The data were organized in an Excel spreadsheet. Descriptive statistics were used for the epidemiological data. In order to verify possible associations between the groups of preceptors from public and private institutions, Pearson's chi-square test was used, with a significance level of 5\%. The software used in the analyses was the Bioestat program, version 5.3 for Windows.

The study was approved by the UNCISAL Research Ethics Committee, via Plataforma Brasil, under CAAE n. 17781419.0.0000.5011, with the Consubstantiated Opinion of Approval n. 3,553,684, issued on September 4, 2019.

\section{RESULTS}

The study involved MR preceptors accredited by the MEC (Ministry of Education) in six hospital units, one in a federal public educational institution, three in state public educational institutions and two in private institutions, in the city of Maceió, state of Alagoas.

The mean age of the preceptors of $43.31+10.31$ years (minimum of 28 and maximum of 77 years). Of these, 149 (74.5\%) were up to 49 years old, thus characterizing a predominantly young population of preceptors (Table 1). Regarding gender, the results showed an evident balance, with a slight majority of female preceptors (52.5\% women and $47.5 \%$ men).

REVISTA BRASILEIRA DE EDUCAÇ̃̃o MÉDICA

3 44(4) : e159; 2020 
The mean time since graduation of the MR preceptors in Maceió was $19.5 \pm 10.58$ (maximum of 51 and minimum of 4 years). Approximately $83 \%$ of the assessed preceptors said they had obtained a Medical degree at Higher Education Institutions in the state of Alagoas, 50.5\% at a Federal Public University and $32.5 \%$ at a State Public University. Only $13 \%$ (26 preceptors) completed their graduation in other federation units of Brazil, and the other $4 \%$ did not inform the institution and place of graduation.

Regarding the performance of postgraduate studies, of the 200 assessed preceptors, 157 declared they had a Medical Residency certification (78.5\%), 10 (5\%) had a specialization in their area and 33 (16.5\%) had an academic degree (11\% had a Master's degree, $4 \%$ had a Doctor's degree and $1.5 \%$ had a Postdoctoral degree), with a mean time since completion of the postgraduate course of $12.63 \pm 10.87$ years, with the mean time of completion of the postgraduate modality being detailed in Table 2.

Of the total number of preceptors, 102 declared they worked exclusively in public educational institutions, where the percentage of master's, doctor's and postdoctoral degrees was $22.55 \%$; whereas of the 66 preceptors who worked only in private hospital units, this percentage was $9.09 \%$, with a statistically significant association $(p=0.0242)$ between preceptors from public institutions and the performance of stricto sensu postgraduate studies (Table 3 ).

The mean time working in preceptorship was $7.07 \pm 6.99$ years, for which the less experienced preceptor reported 1 year and the most experienced one reported 46 years.

Regarding the preparation or training to practice the activity as a preceptor or the pedagogical aspects, it is of concern the fact that 161 (80.5\%) preceptors reported not having performed any kind of training for practicing their function. Only 38 (19\%) preceptors mentioned having had any type of preparation, and a few mentioned the type of training carried out or provided more details on the subject. Another 9 preceptors (4.5\%) mentioned taking preceptor courses in Higher Education Institutions; 8 (4\%) reported having taken preceptorship courses carried out by HospitalSchool initiatives; and 5 preceptors $(2.5 \%)$ had preceptorship courses offered by Medical Specialty Societies. One of the preceptors reported having taken a course in active teaching methodologies and another reported a postgraduate degree in PBL (Problem-Based Learning).

Of the 200 preceptors interviewed for the study, 168 (84\%) work as MR preceptors exclusively in one institution, whether public or private, whereas $16 \%$ (32 preceptors) work in more than one institution. Regarding the type of employment link with the MRPs, a balance was observed between the types of employment links, in which $28 \%$ of the preceptors had a contract of employment; $29.5 \%$ were statutory employees and $29 \%$ were outsourced. Some preceptors declared more than one type of employment link (3.5\%), because they worked in more than one MRP (Table 4).

Most preceptors (58.5\%) reported working in clinical practice with residents between 2 and 3 times a week, while 48 preceptors (24\%) said they worked between 4 and 5 times a week. It should be noted that $82.5 \%$ of the interviewed preceptors worked with their residents between 2 and 5 times a week (Table 5). Also related to their professional practice, $29.5 \%$ of the preceptors reported that they were also teachers at the medical undergraduate course, simultaneously with their work in the MR. Finally, regarding the number of employment links in medical services, there

\begin{tabular}{|ccc|}
\hline \multicolumn{3}{c}{ Table 1 } \\
Profile of preceptors by gender and age group \\
$\begin{array}{c}\text { AGE RANGE (YEARS } \\
\text { OF AGE) }\end{array}$ & MALE & FEMALE \\
\hline$<30$ & $2(\%)$ & N $(\%)$ \\
\hline $30-34$ & $14(7 \%)$ & $4(2 \%)$ \\
\hline $35-39$ & $19(9.5 \%)$ & $24(12 \%)$ \\
\hline $40-44$ & $9(4.5 \%)$ & $30(15 \%)$ \\
\hline $45-49$ & $17(8.5 \%)$ & $10(5 \%)$ \\
\hline $50-54$ & $14(7 \%)$ & $20(10 \%)$ \\
\hline $55-59$ & $5(2.5 \%)$ & $9(4.5 \%)$ \\
\hline $60-64$ & $8(4 \%)$ & $4(2 \%)$ \\
\hline $65-69$ & $3(1.5 \%)$ & $3(1.5 \%)$ \\
\hline$>69$ & $4(2 \%)$ & $1(0.5 \%)$ \\
\hline TOTAL & $95(47.5 \%)$ & $0(0 \%)$ \\
\hline
\end{tabular}

Source: Created by the authors.

\begin{tabular}{|c|c|c|}
\hline $\begin{array}{r}\text { Academic degre } \\
\bmod \end{array}$ & $\begin{array}{r}\text { Table } 2 \\
\text { time of com } \\
\text { of MR prece }\end{array}$ & $\begin{array}{l}\text { ion of the postgraduate } \\
\text { s in Maceió }\end{array}$ \\
\hline Academic degree & N (\%) & $\begin{array}{c}\text { Completion time (Mean } \pm \\
\text { standard deviation) }\end{array}$ \\
\hline Specialization title & $10(5 \%)$ & $24.77 \pm 13.53$ years \\
\hline Medical Residency & $157(78,5 \%)$ & $13.41 \pm 10.84$ years \\
\hline Master's degree & $22(11 \%)$ & $6.36 \pm 4.43$ years \\
\hline Doctor's degree & $8(4 \%)$ & $5.62 \pm 5.50$ years \\
\hline Postdoctoral degree & $3(1.5 \%)$ & $3 \pm 2$ years \\
\hline Total / General & $200(100 \%)$ & $12,63 \pm 10,87$ years \\
\hline
\end{tabular}

Source: Created by the authors.

\section{Table 3}

Association between the institutions and the preceptors' academic degrees

\begin{tabular}{|ccc|}
$\begin{array}{c}\text { Academic degree } \\
\text { (postgraduate) }\end{array}$ & $\begin{array}{c}\text { Public Inst. } \\
\mathbf{N}(\%)\end{array}$ & $\begin{array}{c}\text { Private Inst. } \\
\mathbf{N}(\%)\end{array}$ \\
\hline Lato Sensu & $79(77.45 \%)$ & $60(90.91 \%)$ \\
\hline Stricto Sensu & $23(22.55 \%)^{*}$ & $6(9.09 \%)$ \\
\hline Total & $102(100 \%)$ & $66(100 \%)$ \\
\hline
\end{tabular}

${ }^{*} \mathrm{p}=0.0242-$ Chi-square test

Source: Created by the authors.

was a mean of 2.45 hospitals (minimum of 1 and maximum of 6) per interviewee, where the preceptors worked with or without performing preceptorship activities. 


\begin{tabular}{|c|c|} 
Table 4 & \\
Health institutions and types of employment links related to the \\
MRP preceptors
\end{tabular}

Source: Created by the authors.

${ }^{*}$ CLT: Consolidated Labor Laws or Brazilian Labor Code

\begin{tabular}{|c|c|}
\hline \multicolumn{2}{|c|}{$\begin{array}{c}\text { Table } 5 \\
\text { Weekly frequency working in the MR }\end{array}$} \\
\hline Weekly frequency & N (\%) \\
\hline Once & $33(16,5 \%)$ \\
\hline 2 to 3 times & $117(58,5 \%)$ \\
\hline 4 to 5 times & $48(24 \%)$ \\
\hline Does not know / No answer & $2(1 \%)$ \\
\hline TOTAL & $200(100 \%)$ \\
\hline
\end{tabular}

Source: Created by the authors

\section{DISCUSSION}

The state of Alagoas has followed the national trend of expanding the MRPs, mainly influenced, by the Mais Médicos Program ${ }^{26}$. Between 2014 and 2017, there was a $254 \%$ increase in the offer of vacancies for new residents - R1 - going from 127 to $323^{27}$.

The mean age of the preceptors in this study is similar to the findings of Wuillaume and Batista ${ }^{18}$, who reported in their study that $74 \%$ of the preceptors were aged between 30 and 49 years; as well as those by Souza $^{19}$, in a study with MR preceptors in Anesthesiology, who reported a percentage of $70.1 \%$ aged up to 50 years, also stating that the predominant age group was between 40 and 45 years old. Similarly, Botti ${ }^{12}$, in his Ph.D. thesis, studying a sample of 74 preceptors at a teaching hospital in Rio de Janeiro, showed that $58 \%$ of the preceptors belonged to the age group of up to 49 years. Other studies have shown a younger mean age of the preceptors. Girotto ${ }^{28}$, in a study assessing 327 Multiprofessional Residency preceptors across Brazil, reported a mean age of 37.67 years. Castells ${ }^{15}$, in a qualitative study with 15 preceptors from the Family and Community Medicine residency program in the city of Rio Janeiro, reported a mean age of 30 years, and all preceptors were under 40 years old.
It is interesting to note that the mean age of doctors in the state of Alagoas, in 2018, was $49.5 \pm 13.9$ years ${ }^{8}$, slightly above the mean observed in the present study, thus showing a younger population of preceptors. This difference can be justified by the offer of new Medical Residency Programs in recent years ${ }^{26}$ throughout Brazil, including the state of Alagoas, giving young specialist doctors, newcomers to the job market, the opportunity to develop the activity of preceptorship. Another factor that also has an impact on the age group results from the opening of new medical courses in Brazil, with the entry of a higher number of doctors into the labor market ${ }^{8}$.

Regarding the proportions between the genders, Souza ${ }^{19}$ found similar results to those of the present study, with a predominance of females $(60 \%)$. Some studies diverge from this equilibrium, such as that of Wuillaume and Batista ${ }^{18}$, who reported that $70 \%$ of the preceptors consisted of women. Botti ${ }^{12}$, in turn, found a majority of men $(70 \%)$. However, it is important to highlight that these two divergent studies were carried out in the 2000s, when a predominance of male doctors was observed. According to Scheffer et al. ${ }^{8}$, there were $64.2 \%$ of male doctors in Brazil in 2000 and $35.8 \%$ of female doctors, whereas in 2017 there was a decrease in this difference, with $54.4 \%$ of male doctors and $45.6 \%$ of female ones. Girotto ${ }^{28}$, in a study with SUS preceptors, found a majority of women $(80.73 \%)$, associating this result with the phenomenon of feminization of the health professions. Garcia and Silva ${ }^{29}$, in their study with medical teachers, also reported this process of feminization in teaching at the undergraduate level, and stated that this process occurs, above all, in younger age groups.

Regarding the time since graduation, Wuillaume and Batista ${ }^{18}$ reported data similar to the present study, in which $87 \%$ of their assessed preceptors had graduated from 10 to 29 years ago, of which $56 \%$ had graduated between 10 and 19 years ago. In contrast, Castells ${ }^{15}$ found in his study preceptors with a shorter time since graduation, stating that 93.3\% had up to 9 years since graduation (and no preceptor had more than 25 years since graduation) without reporting the mean time since graduation. In the present study, the large majority of preceptors had graduated in the state of Alagoas, unlike another study ${ }^{15}$, in which only $46.6 \%$ of the preceptors obtained their degree in the same state where the study was carried out (Rio de Janeiro) .

Resolution No. 4/1978, of the National Medical Residency Commission (CNRM), established general rules, minimum requirements and accreditation systematics for Medical Residency. In its article 5, item "d", it determines that the permanent supervision of the Resident's training must be carried out by doctors with a Medical Residence Certificate in the area or specialty or a higher degree ${ }^{30}$. In the present study, 157 preceptors declared that they had at least the MR as an academic degree, which is an indicator of quality, in addition to being in line with the aforementioned resolution. Also, the qualification may also contribute to salary improvement, in situations where this possibility is contemplated in the job and career plan $^{29}$. It is noteworthy the fact that the lato sensu postgraduate program was the first option of most preceptors, with the stricto sensu postgraduate program being carried out later, disclosing a group of preceptors with great professional experience.

Other studies also investigated the proportions of postgraduate degrees among the preceptors, such as Girotto $^{28}$, who identified $14.98 \%$ of preceptors with a Master's degree and 3.36\% with a Doctor's degree,

$5 \mid$\begin{tabular}{l|l} 
REVISTA BRASILEIRA DE EDUCAÇÃO MÉDICA \\
\hline 44 (4) : e159; 2020
\end{tabular} 
whereas Souza ${ }^{19}$ found a higher percentage $(96.6 \%)$ of preceptors with only MR as the highest degree and only 1 (1.7\%) with a Doctor's degree.

Two other studies carried out in university/teaching environments also differed from the results of the present study. Botti ${ }^{12}$ reported that $50 \%$ of their sample had a higher degree than MR, in which $23 \%$ of the preceptors had a Master's degree and $27 \%$ had a Doctor's degree. Wuillaume and Batista ${ }^{18}$ found that $45.5 \%$ of the preceptors had a Master's and/or Doctor's degree, and 53.3\% reported their training consisted only of the Medical Residency. These authors also reported that $33.3 \%$ of the participants were professors at university institutions, and another $44.44 \%$ were assistants at university institutions, which may have contributed to this significant percentage of preceptors with Master's/Doctor's degrees.

Regarding the time since the completion of postgraduate studies, unlike the findings of the present study, Castells ${ }^{15}$ found a group of very young preceptors and with less experience, having reported in their study that $73.4 \%$ of the preceptors reported the time since finishing their MR as being 3 years or less, being in the beginning of their professional life.

About the time of experience as a preceptor in the MR, the data found can be explained by the existence of several MRPs in Maceió with more than 10 years of activity. It should be noted that another study showed different results from those presented here. Girotto ${ }^{28}$ reported in their study that the assessed preceptors' experience with health education was within the range of 0 to 18 years, with a median of 3 years. Wuillaume and Batista ${ }^{18}$ did not report any further details but reported that $49 \%$ of the preceptors had been working for over 10 years. Botti ${ }^{12}$, on the other hand, did not report a mean time, but found more experienced preceptors and a certain balance, in which $30 \%$ had worked as preceptors for up to 10 years, $38 \%$ from 10 to 20 years and $32 \%$ had worked as preceptors for more than 20 years.

Castells ${ }^{15}$, in a study with preceptors from the Family and Community Medicine Residency (RMFC), found that $33.3 \%$ had less than 1 year of experience in MR, $40 \%$ had 1 to 2 years of experience and the remaining (26.7\%) had between 2 and 3 years of experience. No preceptor declared they had more than 3 years of experience. The author justifies this short time of experience by the fact that the evaluated MRPs were implemented only 3 years before the completion of her study.

Regarding the training in preceptorship/teaching, the results obtained in this study can be explained by the limited offer of available training, by the lack of incentives for teacher training and, above all, by the fact that these courses are not mandatory to work as a preceptor. This is a matter of concern, as it is an indication that the pedagogical preparation/ training of the MR preceptor does not seem to be the focus of investment, despite sporadic initiatives ${ }^{23,24,25}$; while also ignoring that these residents in training can become future preceptors. $\mathrm{Cruz}^{16}$ found even more alarming data, reporting that an impressive $92.3 \%$ of the preceptors declared they had no pedagogical training or preparation to perform their MR preceptor functions. According to the author, all preceptors performed their pedagogical functions in an educational institutions.

Souza ${ }^{19}$ reported that $80 \%$ of the assessed preceptors denied having received any kind of pedagogical training to develop the preceptorship activities, and $75 \%$ had no space to participate in the discussion on the teaching-service integration, concluding that this affects all professionals who work as preceptors, and alerting to the importance of discussing the subject of training preceptors aiming to optimize the teaching-learning process in MR. Wuillaume and Batista ${ }^{18}$, in turn, reported a lower percentage, in which $54.44 \%$ of their assessed preceptors did not have specific training for teaching, for research in two institutions, one of which was a teaching institution. Finally, Castells ${ }^{15}$ considered that this lack of preparation for teaching happens because any professional can become a teacher/preceptor, as long as they are experts in their medical area, with no mandatory prior pedagogical or didactic training, resulting in teachers who are specialists in their profession but not educators, teaching from their own experience.

Other authors ${ }^{31}$ also indicate the relevance of the preceptor's training, reiterating that it is essential that these professionals have, in addition to the knowledge of their specialty, pedagogical knowledge to transform their professional experience into learning experiences. Educational institutions have also been deemed responsible for the preceptors' pedagogical training, thus aiming to reaffirm their responsibility with the health of the Brazilian population, strengthening their ties with health and education ${ }^{32}$.

Regarding the weekly hours of work as a preceptor in MR, the results found are similar to the findings of Souza ${ }^{19}$, who reported that $61.7 \%$ of the preceptors in their study work with residents between 2 and 3 times a week. It is important to emphasize the relevance of this finding, as it reinforces the importance of preceptorship and the contact between preceptor/resident for the training of this professional, as well as emphasizing the mandatory follow-up by the resident physician; this less experienced doctor accompanies a more experienced professional (preceptor) on a daily basis, in which coexistence and observation represent the $\mathrm{MR}^{33}$.

Regarding the data on the health institutions where the preceptor works, the fact that public institutions have a greater number of preceptors is due to the fact that they were the pioneers in the state to initiate MR activities, especially the University Hospital of Universidade Federal de Alagoas, an institution that obtained the accreditation of the first MR in Alagoas $^{34}$. Moreover, the main researcher is a doctor at this institution, which facilitated contact with many preceptors and data collection.

The balance found in the present study regarding the aforementioned links between preceptors and the MRPs can be explained by the fact that, amidst the researched institutions, there are public and private hospitals, thus providing preceptors with the most varied employment links, and even with more than one link, as they work in different institutions. Souza ${ }^{19}$ recorded totally different results, reporting that $78.3 \%$ of the study preceptors were outsourced employees and only $10 \%$ had a CLT link.

Regarding the percentage of preceptors also performing activities as teachers in undergraduate medical courses (in addition to their activities as MR preceptors), the results of the present study can be explained by the emergence of new medical courses in Brazil in recent years ${ }^{26}$, including in the state of Alagoas, which currently has five medical schools ${ }^{8}$, giving many specialist doctors the opportunity to also work as a teacher in undergraduate medical courses.

Finally, regarding the activities in medical services, the multiple links found can be explained by the long working hours and the multiplicity of employment links among Brazilian doctors. Maciel et al. $^{35}$, in a study aiming to analyze the multiplicity of doctors' links with SUS in the state of Ceará, concluded that $53.5 \%$ had between 2 and 4 employment links, and $51.9 \%$ had a weekly workload of over

REVISTA BRASILEIRA DE EDUCAÇÃO MÉDICA

6 (44) : e159; 2020 
40 hours. The same authors concluded that doctors had several jobs, even in several municipalities, aiming to increase their income, which contributes to their precarious quality of life.

\section{CONCLUSION}

The data obtained in this study are representative for the universe of preceptors in the MR programs in the city of Maceió, Alagoas, and the results should not be generalized as a profile of preceptors in Brazil, mainly due to the characteristics of each location. However, these results can contribute to a better understanding of the subject, showing a profile of mostly young preceptors, with a slight predominance of females, with a large experience as professionals and as preceptors.

It is noteworthy the fact that only the minority of the interviewed preceptors reported having had some training for working as a preceptor, which is a matter of concern, reflecting little focus on the preparation of the preceptor for performing teaching activities in MR. Once again, the importance of training for preceptorship in MR is emphasized.

It was also observed that the majority of preceptors stated that they work as preceptors only in Public Institutions and had MR as their main qualification, and that public institutions showed a higher number of preceptors with stricto sensu postgraduate qualification, in comparison with private institutions.

Finally, the preceptors had a characteristic of having multiple employment links, working as preceptors or not in several hospital units, reflecting a high workload.

\section{REFERENCES}

1. Brasil. Constituição Federal (Artigos 196 a 200). Brasília, DF; 1988 [access in 10 jul 2020]. Available from: http://conselho.saude.gov.br/ web_sus20anos/20anossus/legislacao/constituicaofederal.pdf.

2. Antunes JM, Daher DV, Ferrari MFM. Preceptoria como lócus de aprendizagem e de coprodução de conhecimento. Rev Enferm UFPE on line. 2017;11(1):3741-8 [access in 18 jul 2020]. Available from: https://periodicos.ufpe.br/revistas/revistaenfermagem/article/ download/22612/24273.

3. Brasil. Decreto $\mathrm{n}^{\circ} \mathbf{8 0 . 2 8 1}$, de 5 de setembro de 1977. Regulamenta a Residência Médica, cria a Comissão Nacional de Residência Médica e dá outras providências. Brasília; 1977 [access in 5 jul 2020]. Available from: https://www2.camara.leg.br/legin/fed/decret/1970-1979/decreto-802815-setembro-1977-429283-normaatualizada-pe.pdf.

4. Brasil. Lei $n^{\circ} 12.514$, de 28 de outubro de 2011. Dá nova redação ao art. $4^{\circ}$ da Lei $n^{\circ} 6.932$, de 7 de julho de 1981, que dispõe sobre as atividades do médico-residente; e trata das contribuições devidas aos conselhos profissionais em geral. Brasília; 2011 [access in 20 jul 2020]. Available from: http://www.planalto.gov.br/ccivil_03/_Ato20112014/2011/Lei/L12514.htm.

5. Sampaio SAP. A implantação da residência médica no Hospital das Clínicas: 40 anos de história. São Paulo: Estudos Fundap; 1984.

6. Carneiro MB, Gouveia VV, coordenadores. O médico e seu trabalho: aspectos metodológicos e resultados do Brasil. Brasília: Conselho Federal de Medicina; 2004 [access in 13 oct 2020]. Available from: https://www.yumpu.com/pt/document/read/40742209/o-macdico-eo-seu-trabalho-brasil-conselho-federal-de-medicina.

7. Brasil. Residência médica. Brasília [access in 5 jul 2020]. Available from: http://portal.mec.gov.br/residencias-em-saude/residencia-medica.

8. Scheffer M, Cassenote A, Guilloux AGA, Biancarelli A, Miotto BA, Mainardi GM, et al. Demografia Médica no Brasil 2018. São Paulo: FMUSP, CFM, Cremesp; 2018 [access in 19 jul 2020]. Available from: http://www.flip3d.com.br/web/pub/cfm/ index10/?numero $=15 \&$ edicao $=4278$.

9. Mills J, Francis K, Bonner A. Mentoning, clinical supervision and preceptoring. Rur and Rem Heal. 2005;5(3):1-10 [access in 26 jul 2020]. Available from: https://www.rrh.org.au/journal/article/410.

10. Botti SHO, Rego STA. Docente-clínico: o complexo papel do preceptor na residência médica. Physis. 2011;21(1):65-85 [access in 3 jul 2020]. Available from: http://www.scielo.br/pdf/physis/v21n1/v21n1a04.pdf.

11. Perim GL, Abdalla IG, Aguilar-da-Dilva RH, Lampert JB, Stella RCR, Costa NMSC. Desenvolvimento docente e a formação de médicos. Rev Bras Educ Med. 2010;33(Supl 1):70-82 [access in 25 jul 2019]. Available from: http://www.scielo.br/pdf/rbem/v33s1/a08v33s1.pdf.

12. Botti SHO. O papel do preceptor na formação de médicos residentes: um estudo de residências em especialidades clínicas de um hospital de ensino [doutorado]. Rio de Janeiro: Escola Nacional de Saúde Pública Sergio Arouca; 2009 [access in 22 jul 2020]. Available from: https:// www.arca.fiocruz.br/bitstream/icict/2582/1/ENSP_Tese_Botti_ Sergio_Henrique.pdf.

13. Soares ACP, Maiorquim CR, Souza CRO, Do Vale DNF, Fujimoto DR, Fagundes FP, et al. A importância da regulamentação da preceptoria para a melhoria da qualidade dos programas de residência médica na Amazônia Ocidental. Cad Abem. 2013; 9:14-23 [access in 12 jul 2019]. Available from: https://website.abem-educmed.org.br/wp-content/ uploads/2019/09/CadernosABEM_Vol09.pdf.

14. Brasil. Resolução CNRM no 02/2006, de 17 de maio de 2006. Dispõe sobre requisitos mínimos dos Programas de Residência Médica e dá outras providências. Brasília; 2006 [access in 15 jul 2020]. Available from: http://portal.mec.gov.br/index.php?option=com docman \&view $=$ download \&alias $=512$ - resolucao $-\mathrm{cnrm}-02-$ 17052006\&Itemid $=30192$.

15. Castells MA. Estudo dos programas de residência médica em medicina de família e comunidade do Rio de Janeiro: a questão da preceptoria [dissertação]. Rio de Janeiro: Escola Nacional de Saúde Pública Sergio Arouca; 2014 [access in 17 jul 2020]. Available from: https://www. arca.fiocruz.br/handle/icict/14860.

16. Cruz JAS. Visão de preceptores sobre o processo de ensinoaprendizagem de residentes de clínica médica [dissertação]. Maceió: Universidade Federal de Alagoas; 2017 [access in 2 jul 2020]. Available from: http://www.repositorio.ufal.br/handle/riufal/2237.

17. Peçanha AJ. Análise e avaliação quanto à quantidade e qualificação dos preceptores das residências médicas em gastrenterologia no Brasil. GED Gastroenterol Endosc Dig. 1994;13(4):157-63.

18. Wuillaume S, Batista NA. O preceptor na residência médica em pediatria: principais atributos. J Pediatr. 2000;76(5):333-8 [access in 25 jun 2019]. Available from: http://jped.com.br/conteudo/00-76-05-333/port.pdf.

19. Souza AAB. Perfil pedagógico da preceptoria da residência médica em anestesiologia da cidade de Manaus [dissertação]. Manaus: Universidade Federal do Amazonas; 2018 [access in 1º jul 2019]. Available from: https://tede.ufam.edu.br/handle/tede/6435/. 
20. Tempski P, Martins MA. Modelos teóricos do processo ensinoaprendizagem aplicados às técnicas de simulação. In: Scalabrini Neto A, Fonseca A da S, Brandão CFS, organizadores. Simulação realística e habilidades na saúde. São Paulo: Atheneu; 2017. p. 1-10.

21. Wuillaume SM. O processo ensino-aprendizagem na residência médica em pediatria: uma análise [tese]. Rio de Janeiro: Fundação Oswaldo Cruz; 2000.

22. Barreto VHL, De Marco MA. Visão de preceptores sobre o processo de ensino-aprendizagem no internato. Rev Bras Educ Med. 2014;38(1):94-102 [access in 4 jul 2020]. Available from: http://dx.doi. org/10.1590/S0100- 55022014000100013.

23. Conselho Regional de Medicina do Paraná. Manual do preceptor de residência médica. Curitiba: CRMPR; 2011. (Série Cadernos do Conselho) [access in 18 jul 2020]. Available from: https://www.crmpr. org.br/uploadAddress/edicao-preceptor[3667].pdf.

24. Pires OGN, Machado JKS, Laraya MHF, Guerra MIP, coordenadores. Manual do preceptor. 3a ed. São Paulo: Sbot; 2020 [access in 21 jul 2020]. Available from: https://sbot.org.br/wp-content/uploads/2020/03/Manual_do_ Preceptor-3a-edi\%C3\%A7\%C3\%A3o.pdf.

25. Brasil. Portaria Interministerial $n^{\circ} 1.618$, de 30 de setembro de 2015. Institui, no âmbito do Sistema Único de Saúde (SUS), como um dos eixos do Programa Mais Médicos - Residência, o Plano Nacional de Formação de Preceptores para os Programas de Residência na modalidade Medicina Geral de Família e Comunidade, com o fim de subsidiar e assegurar instrumentos para o processo de expansão de vagas de residência em Medicina Geral de Família e Comunidade, nos termos da Lei $\mathrm{n}^{\circ}$ 12.871, de 22 de outubro de 2013. Brasília: 2015 [access in 13 jul 2020]. Available from: https://bvsms.saude.gov.br/ bvs/saudelegis/gm/2015/prt1618_30_09_2015.html.

26. Brasil. Lei $\mathrm{n}^{\circ} 12.871$, de 22 de outubro de 2013. Institui o Programa Mais Médicos, altera as Leis no 8.745 , de 9 de dezembro de 1993, e no 6.932, de 7 de julho de 1981, e dá outras providências. Brasília; 2013 [access in 22 abr 2020]. Available from: http://www.planalto.gov.br/ ccivil_03/_Ato2011-2014/2013/Lei/L12871.htm.

27. Brasil. Evolução do número vagas de residência médica autorizadas no Brasil: 2014 a 2018 [access in 22 abr 2020]. Available from: http://portal.mec.gov.br/index.php?option $=$ com_docman \&vi ew=download \&alias=103131- evolucao-de-vagas $-2014-2018$ especialidades\&category_slug=novembro-2018-pdf\&Itemid=30192.

28. Girotto LC. Preceptores do Sistema Único de Saúde: como percebem seu papel em processos educacionais na saúde [dissertação]. São Paulo: Universidade de São Paulo; 2016 [access in 25 jul 2020]. Available from: http://fm.usp.br/cedem/conteudo/publicacoes/cedem_129_dissertacao_ leticia_cabrini_girotto.pdf.

29. Garcia MAA, Silva ALB. Um perfil do docente de medicina e sua participação na reestruturação curricular. Rev Bras Educ Med. 2011;35(1):58-68 [access in 26 abr 2020]. Available from: http://www. scielo.br/pdf/rbem/v35n1/a09v35n1.pdf.

30. Brasil. Resolução CNRM $\mathrm{n}^{\circ}$ 04/78. Estabelece normas gerais, requisitos mínimos e sistemática de credenciamento da residência médica. Brasília; 1978 [access in 18 abr 2020]. Available from: http:// portal.mec.gov.br/sesu/arquivos/pdf/CNRM0478.pdf

31. Ribeiro KRB, Prado ML. A prática educativa dos preceptores nas residências em saúde: um estudo de reflexão. Rev Gaucha Enferm. 2014;35(1):161-5 [access in 26 jun 2020]. Available from: https://seer. ufrgs.br/RevistaGauchadeEnfermagem/article/view/43731/28959.

32. Rocha HC, Ribeiro VB. Curso de formação pedagógica para preceptores do internato médico. Rev Bras Educ Med. 2012;36(3):34350 [access in 16 jul 2020]. Available from: https://www.scielo.br/pdf/ rbem/v36n3/08.pdf.

33. Teixeira DS. Residência médica em Medicina de Família e Comunidade no Rio de Janeiro: o lugar do cuidado na estrutura curricular [dissertação]. Rio de Janeiro: Universidade Federal do Rio de Janeiro; 2009.

34. EBSERH. Ministério da Educação. Hospital Universitário Prof. Alberto Antunes - HUPAA-UFAL. Coordenação de Residência Médica [access in 12 jul 2020]. Available from: http://www2.ebserh. gov.br/web/hupaa-ufal/coordenacao-de-residencia-medica.

35. Maciel RH, Santos JBF, Sales TB, Alves MAA, Luna AP, Feitosa LB. Multiplicidade de vínculos de médicos no estado do Ceará. Rev Saude Publica. 2010;44(5):950-6 [access in 29 jun 2020]. Available from: http://www.scielo.br/pdf/rsp/v44n5/1652.pdf.

\section{AUTHORS' CONTRIBUTION}

Aderval de Melo Carvalho Filho participated in the study concept, data curation, formal analysis, sources of funding acquisition, research, methodology, project management, resources, supervision and writing of the manuscript. Almira Alves dos Santos participated in the study concept, formal analysis, research, methodology, project management, supervision, validation, visualization and writing of the manuscript. Rozangela Maria de Almeida Fernandes Wyszomirska participated in the study concept, formal analysis, methodology, project management, supervision, validation, visualization and writing of the manuscript. Isabella Costa Figueiredo Medeiros participated in the methodology, supervision and writing of the manuscript.

\section{CONFLICTS OF INTEREST}

The authors declare no conflicts of interest.

\section{THANKS}

The publication of this article had the financial support of the Postgraduate Program in Health Teaching and Technology - Professional Master's Degree - at the Universidade Estadual de Ciências da Saúde de Alagoas (UNCISAL), which the authors thank.

\section{ADDRESS FOR CORRESPONDENCE}

Aderval de Melo Carvalho Filho. Rua Dra. Rosa Cabús, 176, Edifício VC Stella Maris, ap. 704, Stella Maris, Maceió, AL, Brasil. CEP: 57035-825. E-mail: adervalfilho@hotmail.com 